\title{
Stratigraphy and sedimentary environments during the Late Quaternary, in the Eastern Bohai Sea (North China Platform)
}

\author{
T Marsset $^{\mathrm{a},{ }^{*}}$, D Xia ${ }^{\mathrm{b}}$, S Berne ${ }^{\mathrm{b}}, \mathrm{Z} \mathrm{Liu}^{\mathrm{b}}, \mathrm{K} \mathrm{Wang}^{\mathrm{b}}$ \\ a Laboratoire "Environnements Sédimentaires", IFREMER-DRO/GM, 29280 Plouzané, France \\ ${ }^{\mathrm{b}}$ First Institute of Oceanography, SOA, Qingdao, China \\ *: Corresponding author : T. Marsset, email address : tmarsset@ifremer.fr
}

\begin{abstract}
:
The Bohai Sea is a shallow sea at the east coast of China. It communicates with the Yellow Sea through a narrow strait. During and since the Late Pleistocene, the Bohai Sea has been a filled subsiding basin submitted to successive regressive-transgressive cycles. In the East Bohai Sea, a number of finger-shaped ridges are present near the strait, where tidal currents are dominant. Veryhigh resolution seismic reflection data have been interpreted relative to sedimentological data provided by a formerly drilled borehole.
\end{abstract}

Seven seismic units are identified and correlated with the following events: units U7-U6 with the Bohai relative sea level rise (65,000-53,000 yr B.P.) and a relative sea level fall (53,000-39,000 yr B.P.); unit U5 with the Xianxian relative sea level rise $(39,000-22,000$ yr B.P.); unit U4 with the period of the late Würm glaciation (22,000-15,000 yr B.P.); units U3-U2 with the transitional period from the end of the Pleistocene to the beginning of the Holocene (15,000-9000 yr B.P.); and unit U1 with the Holocene (Huanghua) marine intrusion in the Bohai Sea (since 9000 yr B.P.).

In the Bohai Sea, formation of the tidal ridges is probably due to a substantial increase in tidal-current velocities during the late Holocene rise of sea level. Constriction due to the strait amplifies the tidal process, so that the sediments of the late Holocene transgressive sequence have been remodeled as tidal ridge.

Keywords: Eastern Bohai Sea; Late Pleistocene; stratigraphy; relative sea level variations; tidal ridges; very-high resolution seismic 


\section{Introduction}

The Bohai Sea is a subsiding basin where up to 10 kilometers of sediments have accumulated since the Cenozoic. Because the maximum water depth reaches only 30 metres in the area and the average depth is only 18 meters, the Bohaï Sea has been strongly affected by Quaternary sea-level changes. These changes, combined with variations in sediment supply and climate, caused a complex pattern of sedimentary units linked to drastically different sedimentary environments.

The aim of this paper is to reconstruct the sedimentary evolution of the Bohai Sea during the Late Quaternary, based on Very High Resolution seismic reflection investigations related to previous work by Chinese scientists and based on sedimentologic and stratigraphic analyses. These geophysical investigations were carried out in 1991 within the framework of a Chinese-French cooperation in oceanography between the State Oceanic Administration in China and the French Oceanographic institute IFREMER in France.

\section{General setting}

The studied area $\left(3000 \mathrm{~km}^{2}\right)$ is in the eastern part of the Bohaï Sea, bounded by the Laotieshan Channel and the Bozhong and Liaodong shoals (fig. 1).

\section{Structural setting}

The Bohaï Basin in East China belongs to the North China platform (Hu et al., 1989). It is a of Meso-Cenozoic age cratonic fault-bounded basin (fig. 2). Faulted depressions and deformations of strata are controlled by block-faulting activities. During the Mesozoïc, NE - trending rifts formed and filled with $1000-1500 \mathrm{~m}$ of sediments. During the Cenozoïc, the Bohaï Basin formed and connected with the North China Basin inland.

The Bozhong depression in the center of Bohaï Basin is the main structural unit. Cenozoïc deposits there exceed $10 \mathrm{~km}$ in thickness. Two fault systems, striking NE ENE and NW-WNW respectively, controlled the distribution of uplifts and depressions in the basin. The NE- striking Tancheng - Lujiang fault extends along the east border of the Bozhong depression. The eastern boundary of the Bohaï Basin is the ShantungLaoyehling Massif (fig. 1a), a major structural high. This massif is now submerged at the strait of the Bohaï Sea (Laotieshan Channel). Several prominences of this massif, like the Miaodao Islands, emerge in the strait (fig. 1b). 
The study area is located in the middle part of the Tancheng-Lujiang fault system, NW of the Laotieshan Channel.

\section{Late Quaternary sea-level history}

The Quaternary deposits, more than $400 \mathrm{~m}$ thick, consist of alterning marine and continental layers.

Four relative sea level rises during the Late Pleistocene are identified onshore by Qin et al., 1990 : Cangzhou (108,000 to 70,000 Y. B.P.; 2 pulses), Bohaï $(65,000$ to 53,000 Y.B.P.), and Xianxian (39,000 to 22,000 Y.B.P.).

The bathymetric chart of the Yellow Sea shows that the $100 \mathrm{~m}$ isobath does not enter the Yellow Sea basin (fig. 1a). As a result, the entire Yellow Sea basin was subaerially exposed during the last lowstand of sea level (Geng, 1982; Peng et al., 1984; Butenko et al., 1985). The Huanghua transgression (9,000 to 2,000 Y.B.P.) during the Holocene is identified by Qin et al.(1990) who indicate that sea level reached a maximum between 6,000 and 5,000 Y. BP. However, a study of coastal dunes and peat deposits around the Bohaï Sea suggests that sea level reached the highest position twice during the Holocene, at about 6,000 y. BP and 2,000 y. BP (Gao and $\mathrm{Li}, 1985$ ).

The Shantung-Laoyelling massif between the Bohaï Sea and the Yellow Sea has been progressively eroded during late Quaternary. The present channel through this old massif was eroded (by waves?) during the Holocene and the present Miaodao islands were formed at the end of the Huanghua transgression (Qin et al., 1990).

\section{Physical regime, sediment sources and bedforms}

The tidal range is less than $2 \mathrm{~m}$ in the central part of the Bohaï Sea, and more than $5 \mathrm{~m}$ in the western and northern embayments. Due to the Coriolis force, the flood (dominant current) enters along the North side of the Laotieshan Channel and turns northward (fig. 3). The ebb current flows out along the south part (Qin et al., 1990; Fang, 1994). Surface-current velocities are about 2 to 3 knots in the central part of the Sea, but reach more than 5 knots in estuaries and in the Laotieshan Channel (Fang, 1994). In that channel, the sediment transport capability is more than $1,000,000$ $\mathrm{m}^{3} / \mathrm{y}$., and no deposition occurs (Qin et al., 1990). In the Liaodong shoals, current velocity $1 \mathrm{~m}$ above the sea floor reaches 2.2 knots during flood and 1.9 knots during ebb (Liu et al., 1994). In addition, currents related to the extension of the Kuroshio warm current induce an anticlockwise circulation in the Bohaï Sea. However, a clockwise circulation may develop seasonally in the northeastern part of the Bohaï Sea. The maximum surface velocity related to that circulation does not exceed 0.4 knots (Guan, 1994). During winter, northerly winds and waves are dominant. Both are 
weaker and more scattered during summer. Annual average wave height is $1.1 \mathrm{~m}$ in the central Bohaï Sea. Occasionally, typhoons occur in the Bohaï Sea. In 1972 one induced waves 3.6m high in the Laotieshan Channel (Qin et al., 1990).

The distribution of sediments in the Bohaï Sea is closely related to dispersal of suspended materials from rivers (Qin et al., 1990). Coastline morphology, seabottom morphology, and hydrodynamic conditions also play a major role in trapping the sediments. Most of the Bohaï Sea is blanketed with fine sediments, which are presently supplied by rivers (especially the Huang He / Yellow River). Only the study area (Bozhong and Liaodong shoals) and the Laotieshan Channel present coarser sediments (Qin and Li, 1983). On the shoals, the sediments are well sorted fine sands (Liu et al. , in preparation). In contrast, in the channel, coarser sediments, including gravel (max. size : $15 \mathrm{~cm}$ ), are evidence of more intense sediment transport.

The Liaodong shoals consist of six finger-shaped ridges, up to $50 \mathrm{~km}$ long, which converge toward the west side of the Laotieshan Channel. Their maximum height is about 15 metres above the surrounding sea floor, so that their highest part is only submerged about $10 \mathrm{~m}$ (Liu and Xia, 1986). The shape and orientation of superimposed bedforms (dunes, comet marks...) indicate that they are in equilibrium with the present tidal regime (Liu et al., 1994).

\section{Methods}

A geophysical investigation (fig.1b) was carried out in October 1991 with the Chinese Research Vessel Xiang Yang Hong 9. Very High Resolution acoustical systems from IFREMER were employed simultaneously: an EGG SMS 960 side scan sonar, an EDO 515 sub-bottom profiler, a SIG sparker and a FURUNO narrow beam echo sounder. A total of 38 profiles (with a total length of $714 \mathrm{~km}$ ) were recorded with an accuracy of a few meters for the positioning given by the DGPS system. In addition, current measurements, grab samples, and vibracores were obtained by S.O.A. to calibrate acoustic imagery (Liu and al, in preparation). One of these lines was shot over a borehole performed by the Chinese Academy of Sciences (BC1 in fig. 1b) in order to calibrate the seismic facies.

\section{Results}

Seismic units, unconformities and internal reflectors 
Seven major units were identified on the seismic records and were labelled U1 to $\mathrm{U} 7$ from the top to the bottom. Figures 4 and 5 present the seismic characteristics of these units for a section of profile 1 (location on fig. 1b).

These units are bounded by major unconformities characterized by substantial erosional truncation and/or as distinct seismic-facies boundaries. They are laterally extensive through large distances $(130 \mathrm{~km})$. Within these units, many distinct internal reflectors (clinoforms, hummocks, etc...) are present but not always clearly delineated, often due to the presence of gas.

Units U3 to U7 were observed on the sparker profiles but not on the $2.5 \mathrm{khz}$ sub-bottom profiler due to its lower penetration (around $40 \mathrm{~ms}$ twtt). More information is known for units $\mathrm{U} 2$ and $\mathrm{U} 1$ due to the very high resolution of the 2.5 Khz sub-bottom profiler.

The description of the seismic units is done from the bottom to the top, in chronologic order (fig. 4).

Units $\mathbf{U} 7$ and $\mathbf{U} 6$ are both characterised by a transparent homogeneous acoustic facies at the bottom and very low-energy subparallel reflectors suggesting homogeneous fine sediments. At the top, subparallel reflectors, horizontal or gently dipping and sometimes wedging are observed. Tops of both units are incised by channels probably formed during a relative sea-level fall (fig. 4). Major unconformities overlying infilled channels could be interpreted as ravinement surfaces.

Unit U5 presents, from bottom to top, a progressive variation from a transparent homogeneous acoustical facies to increasingly bedded, wedging stratification.

Unit U4 presents discontinous and chaotic reflectors, either parallel or sigmoidal clinoforms, with alternating phases of higher and lower energy. In some places, lenticular bodies with clinoforms do not exhibit topset terminations but have a sharp toplap termination suggesting that the overlying seismic unconformity is an erosional surface. This acoustic facies suggests high energy environments, such as upper shore face, estuarine, fluvial or even aeolian environment.

Unit U3 is characterised by two distinct facies. At the bottom, subparallel reflectors are in apparent onlap on unit U4. In the upper part, gently dipping reflectors wedge out, to form a very large-scale compound cross stratification. Large variations of the seismic amplitude within this seismic facies suggest interbedded layers with different lithologies. The top of unit U3 is bounded by an unconformity overlying occasionally infilled channels.

Unit U2 displays two to four sub-parallel, sub-horizontal reflectors, interrupted by several incised channels or depressions (fig. 5). The interpretation is 
often obscured by acoustic masks, probably related to gas/peat layers, especially in the inner part of the study area (fig. 12). The chaotic facies within the infilled channels suggest the presence of coarse sediments, whereas the sub-parallel reflectors could correspond to finer material. The position of the different channels indicates several stages of erosion. However, the lack of dense three-dimensional seismic mapping does not allow us to determine whether these stages of erosion are related to base-level changes or to migration of fluvial and/or deltaic channels during protracted aggradation. Units $\mathrm{U} 2$ and $\mathrm{U} 1$ are separated by an erosional unconformity, with a strong contrast in acoustic impedance.

Unit U1, characterised by a low-amplitude and homogenous acoustic facies, displays sub-parallel and continuous reflectors. This acoustic facies suggests low energy sedimentary environment, with fine-grained sediments. However, in the Liaodong shoal, the upper part of $\mathrm{U} 1$ is modeled by large sandy bedforms such as sand ribbons and dunes (Liu et al, in preparation).

\section{Correlation between seismic units and Borehole BC1}

Seismic-reflection profile 1 was shot to correlate the main seismostratigraphic units of the area of study with the sedimentologic and chronostratigraphic information from a borehole $240 \mathrm{~m}$ long at the west edge of the study area (Qin et al., 1990). These authors identified pollens, foraminifers, ostracods, and molluscs, made grain-size analyses (classification, sorting), described sedimentary structures, determined magnetostratigraphy, and obtained ${ }^{14} \mathrm{C}$ age dates. These data allowed Qin et al. (1990) to reconstruct the evolution of depositional environments and the changes in sea level, climate, sediment supply and tectonics since 165,000 y. B.P. It is worth noting that the chrono-stratigraphical scale is based on ${ }^{14} \mathrm{C}$ dating technique and extrapolates sedimentation from rate calculations.

The seismic units described in this paper match the lithologic units from the upper $110 \mathrm{~m}$ of the borehole, as synthesized in figure 6 . Relatively detailed correlations can be proposed:

The lower part of unit U7, corresponding to a transparent acoustic facies, consists of silty sand. Types of foraminifera and ostracods suggest a littoral marine environment. These deposits correspond to the end of the Bohaï transgression $(65,000$ to 53,000 Y.B.P.) which has been described in the center of the Bohaï Sea as a small and short relative sea level rise (Qin et al., 1990). Assemblages of spores and pollen are indicative of a mild and warm climate : deciduous broadleaf trees are abundant and Chenopodiaceae and Artemisia are the most abundant herb pollens.

The upper part of unit U7, characterised by subparallel reflectors, corresponds to a progressive change from fine sand to interbedded layers of silt and 
clay. Faunal assemblages indicate a limnological environment whereas sporo-pollen assemblages witness a cool to cold and rather dry climate, dominated by coniferous and grassland species. This period corresponds to a relative sea level fall. For example, these changes are marked by an enrichment in terrestrial molluscs (Gyraulus albus) at the top of U7 (-62m), and changes in ostracods from Sinocytheiridea impressa (marine ostracod) between $-72 \mathrm{~m}$ and $-66 \mathrm{~m}$ (upper part of U7) to llyocyocypris gibba (lacustrine ostracod) in the top of U7 (-62 m) (Qin et al., 1990). The major unconformity and infilled channels observed at the top of unit U7 on the seismic section could correspond to continuation of this relative sea-level drop.

The comparison with borehole data indicates that the transparent acoustic facies in unit U6 corresponds to interbedded layers of clay and silt. These deposits are terrestrial (limnologic environment), and faunas and pollen indicate that the climate remained cold and dry during the whole interval. By contrast with U7, grass pollen became dominant with respect to conifers. Despite a clear expression on the seismic profiles, unit U6 is not clearly identified in previous studies (Qin et al., 1990). However, the seismic boundaries correspond well to changes in the sediment ratio (increase in sand content from the bottom to the top of U6), as seen in figure 6, and in faunal assemblages. For example, the lacustrine ostracod llyocyocypris gibba appears in the upper part of $\cup 6(-50 \mathrm{~m})$.

Within Unit U5, the transparent acoustic facies correponds to clayey silt. Molluscs suggest an epicontinental environment (water depth about 20-30 m). At the top, the presence of carbonate muds and one peat layer (about $-42 \mathrm{~m}$ ) reveals a shallowing at the end of the interval, with some lacustrine deposits. This layer has been dated at $26.8 \mathrm{ky}$. The climate was warm and slightly moist. Unit U5 corresponds to the Xianxian relative sea-level rise $(39,000-22,000$ Y.B.P.) characterised by the most extensive landward coastline migration (Qin et al., 1990).

Unit U4 corresponds in the borehole with homogeneous layers with a large amount of fine sands which can be observed in many borehole drilled around the studied area. This well sorted and rounded sand is interpreted by Qin et al. (1990) as of windborne origin. The pollen and fauna indicate a dry climate and the coldest period during the last part of the Late Pleistocene. The discovery of loess deposits, found to the South-East of the Bohaï Sea (Miaodao Islands and North coast of Shandong peninsula) emphasize the aeolian origin of the deposits (Qin et al., 1990, Xia et al. 1991). The loess deposits are dated of 20,000 to 12,000 Y.BP, mostly 18,000 Y.BP (Wang and Sun, 1994). According to pollen data, the Beijing region (west of the study area) at that time had a desert climate. Furthermore, the area around the Bohaï Sea was far from the sea. Desertized landscape such as sand dunes could occurred in the central Bohai Sea and to the North East (Xia et al., 1994; Liu and Xia, 1992; Liang and Zhang, 1991, An et al., 1991). 
For these reasons, it is suggested that the prograding clinoforms observed on some seismic lines within unit U4 could be crossbeds produced by aeolian dunes (fig. 4), rather than fluvial or tidal deposits. The middle part of the Liaodong Bay (in the northeast part of the Bohai Sea) at that time was a lake formed by the convergence of the Liaohe River, the Dalinghe River and the Luanhe River (Li and Lin 1984). It is possible that some lakes also formed in the study area, which would explain the presence of some transparent homogeneous reflectors within unit U4.

Unit U3 corresponds to layers of silty clay, with terrestrial molluscs and ostracods which are indicative of lake and pond environments. The pollen indicate a moister climate, compared to unit U4. No ostracods were found between 26 and $17 \mathrm{~m}$.

Unit U2 (continuous, well-marked reflectors incised by channels) corresponds to alternating layers of sand and silt. These deposits are composed mainly of materials derived from river transportation and coastal erosion (Qin et al. , 1990). The molluscs indicates a lake or pond environment. The bottom of $U 2$ (at $-13 \mathrm{~m}$ ) is marked by a peat layer about $40 \mathrm{~cm}$ thick, which may be correlated with the acoustic mask commonly observed in the seismic profiles. This peat layer yielded a ${ }^{14} \mathrm{C}$ age of about 13,490 Y. B.P. and presents a transition from a continental facies to a marine one. In this area, the sporo-pollen data confirm a general warming after 13,000 Y. B.P. Rainfall increased, rivers and lakes developed and vegetation gradually became luxuriant, so that the dry desert landscape progressively changed to a steppe and forest landscape. In contrast with unit $\mathrm{U} 3$, the various seismic facies observed in Unit U2 may be explained by the development of a large number of infilled river channels, marsh depressions and tidal flats.

The acoustically homogenous unit U1 consists of fine marine sediment (from silty sand to clayey silt). According to Qin et al. (1990), the sea began intruding the Bohaï Basin about $9,000-8,500$ - Y. B.P. during the Holocene $(11,000$ Y. B.P. to present) reaching its present position about $6,000-5,000$ Y.B.P. Thus, the major surface seen on the profiles at the bottom of U1 could correspond to the surface buried during the last relative sea level rise. The sediment is rich in foraminifers, and microfossils increase distinctly from bottom to top. The types of ostracodes, molluscs and foraminifers suggest a marine neritic environment similar to the present one (water-depth about 20-30 m). The sporo-pollen assemblages indicate a climate similar to the present climate. However, a cooler and moister period can be identified from $5 \mathrm{~m}$ to $1.70 \mathrm{~m}$ in core $\mathrm{BC} 1$. As mentioned above, unit $\mathrm{U} 1$ is dominated by horizontal stratification, evidence for weak hydrodynamic conditions.

\section{Lateral evolution of the seismic units from the Laotieshan Channel}

\section{to the Bozhong shoal.}


The lateral changes in lithofacies from the Laotieshan Channel to the Bozhong Shoal probably are not very substantial, because the seismic facies observed along profile 1 show few changes. However, important changes in the thickness es of the units are observed. They suggest a lateral variability in the relative rates of deposition and erosion through time.

A simplified line drawing combining information from both sparker and subbottom profiler records (fig. 7) summarizes these observations. In addition, selected seismic sections are shown in figures 10,11,12 and 13.

Unit U1: The present surface of the Bozhong Shoal is clearly erosive, because the sea-floor surface truncates all major internal reflectors. Similar features are observed within the Liaodong Shoal (fig. 8). Moreover, unit U1 pinches out on the west flank of the Laotieshan channel, probably because of tidal erosion by currents. It thickens in the central part of the Bohai Sea, reaching more than $20 \mathrm{~m}$ in the Bozhong and Liaodong shoals. The unconformity between $U 1$ and $U 2$, near the base of transgressive deposits, is strongly apparent on most profiles, except where it is obliterated by acoustic masks.

Unit U2 : Its thickness ranges from 2 to $8 \mathrm{~m}$, with an average of about $4 \mathrm{~m}$. It pinches out in the Laotieshan Channel, due to strong erosion.

Unit U3 and U4 : The lack of sparker data along the eastern part of the profile makes difficult determination of the thicknesses of these units laterally. However, the mean thickness is of about $10 \mathrm{~m}$ for each unit. Deposits of the same age have been cored at borehole BC1 and along the west coast of the Bohaï Sea (Qin et al, 1990). At the outlet of Laotieshan Channel, where the water depth is greater than 45 $\mathrm{m}$, unit U3 crops out. On profile 1 (fig.7), the buried paleo-channels incised in U3 are deeper and more closely spaced in the Laotieshan Channel. The largest of these buried channels is over $1 \mathrm{~km}$ wide.

\section{Discussion}

\section{Major regressive-transgressive events in the Bohaï Sea}

The major transgressive events that have been distinguished in the previous studies in the Bohaï Sea are the Upper and Lower Cangzhou $(108,000-70,000 \mathrm{Y}$. B.P), Bohaï (65,000 - 53,000 Y.B.P) Xianxian (39,000 - 22,000 Y.B.P), and Huanghua (9,000 Y.B.P) events (Qin et al., 1990). The paleomagnetic measurements (magnetic inclinations and intensities) and ${ }^{14} \mathrm{C}$ dating show that the Cangzhou transgression occurs at the end of the Blake paleomagnetic event (114,000 108,000 Y.B.P), the Xianxian transgression corresponds to the Mungo excursion 
(36,000 - 35,000 Y.B.P) and the stratigraphic boundary between the Late Pleistocene and the Huanghua transgression belongs to the Göthenburg $(13,750$ $-12,350$ Y.B.P) paleomagnetic event (Qin et al., 1990). The Bohaï transgression, considered a secondary event restricted to the central Bohaï Sea, is associated with a short and unnamed reversal in the geomagnetic polarity $(X 2: 60,000-50,000 \mathrm{Y}$. B.P., Qin et al. 1990).

The seismic analysis shows that an important event, corresponding to the U7U6 boundary, took place between the Bohaï and the Xianxian transgressions. This event is not directly observed in the lithology which indicates interbedding of clay and silt deposits from 49.2 to $79.6 \mathrm{~m}$ in $\mathrm{BC1}$ (fig. 6). However, as described above, careful analysis of borehole $\mathrm{BC}-1$ shows significant changes in sediment ratios (sand/clay content) and faunistic assemblages, corresponding to the bounding seismic surface between $U 7$ and $U 6$. Moreover, this event corresponds to a paleomagnetic event recorded at $55 \mathrm{~m}$ in $\mathrm{BC1}$, i.e. within unit U6. This event $(\mathrm{X} 1)$ has not been dated.

\section{Correlation among seismic units, Borehole BC1, and glacio-}

\section{eustatic curve SPECMAP.}

The results of analysis of the borehole $\mathrm{BC} 1$ and seismic data can be compared with the oxygen-isotope curve (fig.9) used as a proxy for sea level (SPECMAP curve of Imbrie et al., 1984; Pisias et al., 1984).

The lower part of the seismic unit U7 corresponds to the Bohaï transgression $(65,000$ to 53,000 Y.B.P.) restricted to the central part of the Bohai Sea. It corresponds well to the sea level rise between stage 4 and stage 3 , as identified in the SPECMAP curve (fig. 9). However, Qin et al. (1990) also claim a tectonic origin for this relative sea level change, in relation with the recent activity of the Tangcheng Lujiang fault system. The alterning terrestrial and marine stratigraphic interval in the upper part of the seismic unit $U 7$ is contemporaneous with the beginning of regressive period after the Bohaï trangression.

Unit U6, which shows only small changes in faunas and lithologies could be explained by a glacio-eustatic fluctuation of sea level during the isotope stage 3.3.

In Unit U5, the distinct stratigraphic change from the terrestrial facies (top of unit U6) to a shallow-marine facies (bottom of unit U5) is related to the beginning of the Xianxian relative sea level rise $(39,000$ to 22,000 Y.B.P.). This period corresponds to the sea level rise before stage 3.0.

Unit U4 consists of large-scale clinoforms interpreted as aeolian deposits, and corresponds well to isotope stage 2 (last glacial maximum) 
Unit U3, whose reflectors seem to onlap the underlying unit, corresponds to an increase in rainfall at the transition from isotope stage 2 to stage 1 , as demonstrated by the pollens.

Unit U2 corresponds to the beginning of isotope stage 1. The warming is confirmed by the increase in pollen from broad-leaved trees. The incised structures could correspond either to fluvial and/or estuarine channels.

The lower boundary of Unit U1 corresponds to the Huanghua relative sea-level rise. Deposition began between 8,500 Y.B.P., in the deepest part of the Bohaï Sea, and about 5,000 Y. B.P., in the shallowest zones. This period belongs to the Holocene and is related to isotope stage 1

It must be noted that units U5, U6 and U7 don't correspond to well constrated seismic and lithologic $(U 6, U 7)$ characters. This may reflect the numerous minor climatic changes between isotopic stages 4 and 2 .

\section{The Holocene transgressive sequence and the formation of the}

\section{Bozhong and Liaodong Shoals}

The Bozhong Shoal, up to $18 \mathrm{~m}$ thick along profile 1, represents the latest part of the Holocene transgression and subsequent high stand. It exhibits internal reflectors, most of which have a very gently apparent dip to the NW (fig. 8a). The seismic facies suggest deposition in a low-energy environment, with limited reworking. However, two of internal reflectors of unit U1 (fig. 8a) corresponding to small steps in the external morphology, could be related to sea level pulsations (around 6,000 and 2,000 Y. B.P.), as mentioned by Gao and Li.(1985). This assumption requires future investigation in three dimensions for deciphering global factors from possible local factors. It must be noted that the stratigraphic analysis of the borehole core also indicates that the upper $5 \mathrm{~m}$ of $\mathrm{U} 1$ corresponds to a marine environment similar to the present one, whereas the lower part of $U 1$ (below $8 \mathrm{~m}$ ) corresponds to an estuarine environment.

The surface of the Bozhong and Liaodong Shoal are erosional surfaces, truncating the underlying reflectors. These surfaces are evidence for a recent change in the hydrodynamic (tidal ?) regime. It may be hypothezised that the tidal influence has increased during the final stage of relative sea-level rise, wherein a small increase in water depth caused a large change in amplitude of tides. More generally, a resulting increase in tidal currents could also explain the appearence of erosion area around the Liaodong Shoal and in the west part of the central Bohaï Sea.

Such hydrodynamic changes during the Late Holocene could explain the redistribution of a part of sediments constituting unit $U 1$. As mentioned above, the Liaodong shoal is characterised by superimposed bedforms in equilibrium with the 
present tidal regime (Liu et al., 1994). Shoals formation could be related to the erosion and redeposition of the Holocene transgressive sequence due to the influence of tidal currents. .

\section{Conclusions}

The evolution of sedimentary environments in the Bohaï Sea during the Late Quaternary can be reconstructed from analysis of seismic and sedimentological data. Glacial-eustacy and changes in sediment volume and caliber, due to climatic changes, and the influence of local tectonism have controlled the sedimentation. Because of the low slope gradient in the Bohai Sea, small changes in relative sea level could have been recorded, like the pulses within isotope stage 3 . Typical layers like aeolian deposits related to the last glacial maximum (isotope stage 2), are present throughout the Bohaï Sea. Both basinal subsidence and fault-caused tectonics (related to the Tangcheng Lujiang fault system) should be taken into account for understanding the changes in accomodation space.

Despite an abundant sediment supply, the present topography of the eastern Bohai Sea is largely erosional in origin because of the strong tidal currents. The shoals belong to a general transgressive system (Holocene) ultimately reworked by recently strong tidal currents, possibly due to an increase in tidal range. An increase in tidal currents could explain both the erosional nature of the sea floor and the accumulation of tidal bedforms at the tops of some of the ridges (Liaodong Shoal).

\section{Acknowledgments}

We thank the Directors of State Oceanic Administration and IFREMER for permitting the organization of this investigation, within the framework of the Chinese-French agreement in Oceanography. The French Foreign Affairs Ministry and the French Embassy in Beijing are thanked for funding travels and providing assistance.

P. Cirac (University of Bordeaux) is thanked for his help during acquisition of the data at sea. Captain Y. Xin and the crew of the S.O.A.research vessel Xiang Yang Hong 9, as well as S. Han, Y. Ding, Zh. Liu, D. Chong, C. Xu, X. Zhou, P. Li, D. Zhong, X. Xu, L. Petit de la Vileon, C. Prudhomme, and J.M. Raillard are thanked for their technical assistance during the survey and/or for the data processing.

Doctor R.Q. Oaks () and an anonymous reviewer are thanked for their helpful advice towards improving earlier draft of the manuscript. 


\section{References}

Alexander, C.R., DeMaster, D.J. and Nittrouer, C.A.., 1991. Sediment accumulation in a modern epicontinental-shelf setting : The Yellow Sea. Mar. Geol., 98: 51-72

An, Z. et al., 1991 : Paleomonsoon in China since 130 Ka B.P.. China science, 11: 1210-1212

Butenko, J., Milliman, J.D. and Ye, Y., 1985. Geomorphology, shallow structure and geological hazards in the East China Sea. Cont. Shelf Res., 4: 121-141

Fang G., 1994. Tides and tidal currents in east China sea, Huanghaï sea and Bohaï sea. In: Zhou D. et al. (eds), Oceanology of China Seas, 1: 101-112

Gao, S. and Li, Y., 1985. Sea level fluctuation along the northern coast of Bohaï gulf about 2, 000 Y. BP. Acta Oceanologica Sinica. Vol.4 n² : 244-253

Geng, X., 1982. Marine transgressions and regressions in East China since the last Pleistocene Epoch. Collect. Oceanic Works, 5: 100-123

Guan, B., 1994. Patterns and structures of the currents in Bohaï, Huanghaï and east China seas. In : Zhou D. et al. (eds), Oceanology of China Seas. Kluwer Academic Publishers, Vol.1: 18- 26

Hsu, H., 1986. New ideas from seismic stratigraphic and sedimentologic studies of paleogene sediments of the East Coast Region of China. CCOP/ TP; ISSN 0252-5720; INT; DA. 1986; Vol. 17; PP. 25-61

Hu, J., Xu, S., Tong, X. and Wu, H., 1989. The Bohaï Bay Basin. In : Chinese Sedimentary Basins, pp. 89-105, Zhu X. (editor), Sedimentary Basins of the world, 1 (Series Editor K.J. Hsü), Elsevier.

Imbrie, J., Hays, J.D., Martinson, D.G., McIntyre, A., Mix, A.C., Morley, J.J., Pisias, N.G., Prell, W.L. and Shackleton, N.J., 1984. The orbital theory of Pleistocene climate: Support from a revised chronology of the marine d180 record. In : Milankovitch and Climate. Part 1 (A.L. Berger er al. eds), pp. 269-305. Reidel, the Nederlands. 
Li, F. and Lin, M. , 1984. Paleogeomorphological units and relicts left over from the late pleistocene in the Liaodong Bay. Studia Marine Sinica, 23: 57-67 (in Chinese).

Liang, M. and Zhang, J. (eds), 1991. Correlation of onshore and offshore Quaternary in China. Science Press, Beijing, China, P.5-11, 167-168, 188-194 (in Chinese).

Liu, Z. and Xia, D., 1986. Submarine sand ridges. In : Modern sedimentation in the coastal and nearshore zones of China (Ren ed.)

Nanjing University, Department of Geology, China

Liu, Z. and Xia, D., 1992. Sediment characteristics of ancient desert in Bohaï Sea. In : Acta Sedimentologica Sinica, Vol.10, № 2

Liu Z., Xiu D., Tong U., Wang K., Berné S., Marsset T., Bourillet J.F., 1994. Holocene tidal sedimentary system of east Bohai Sea. Science in China, 12, 1331-1338.

Peng, F., Sui, L., Liang, J. and Shen, H., 1984. Data on lowest sea level of east China Sea in Late Pleistocene. Sci. Sin. (Ser. B), 27: 865 - 876

Pisias, N.G., Martinson, D.G., Moore, T.C., Shackleton, N.J., Prell, W., Hays, J. and Boden, G., 1984. High resolution stratigraphic correlation of benthic oxygen isotopic records spanning the last 300000 y. Mar. Geol., 56: 119-136

Qin, Y. and Li, F., 1983. Study of influence of sediment loads discharged from the Huanghe river on sedimentation in the Bohaï sea and the Huanghai sea. In : Proceedings of International Symposium on Sedimentation on the continental shelf, with special reference to the East China Sea. China Ocean Press, Beijing.

Qin, Y., Zhao, Y., Chen, L., Zhao, S., 1990 : Geology of the Bohaï Sea. Institute of Oceanology, Academia Sinica

Wang, P. and Sun, X., 1994. Last glacial maximum in China : comparison between land and sea. Elsevier Science. Catena 23: 341-353

Wang, S., 1994. The geology and petroleum resources of Northern China seas. In : Oceanology of China Seas, 2: 347-360, Zhou D. et al. (eds.)

Xia, D. et al., 1991. Speculations on the paleodesert in the Bohaï Sea, Acta Oceanologica Sinica, 13 (3): $541-545$ (in Chinese) 
Xia, D. et al., 1994. Discussion on the cut-off supply of the Huanghe River in the last glaciation : submitted to Chinese in Oceanologia et limnologia Sinica. 


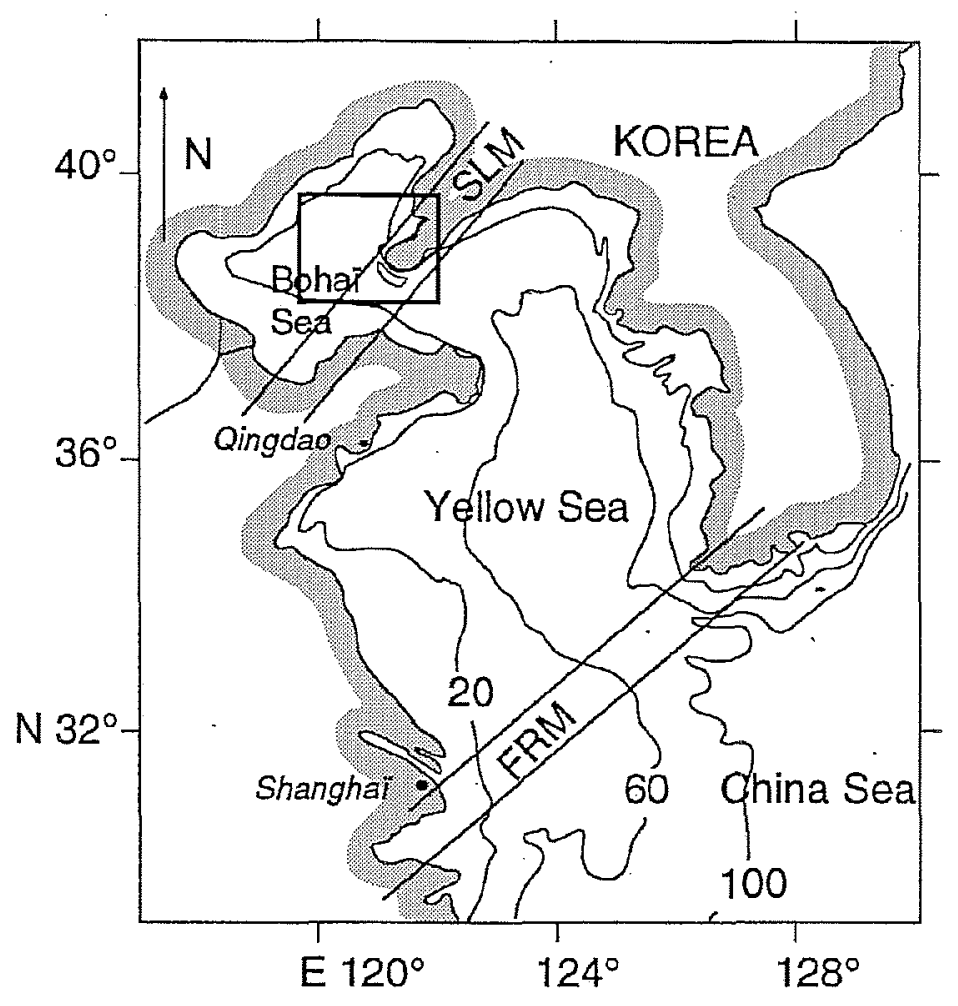

SLM : Shantung-Laoyehling Massif FRM : Fukien-Reinan Massif

fig. 1a : original setting of the study area (modified from Alexander et al., 1991)

fig. 1 : location of the study area

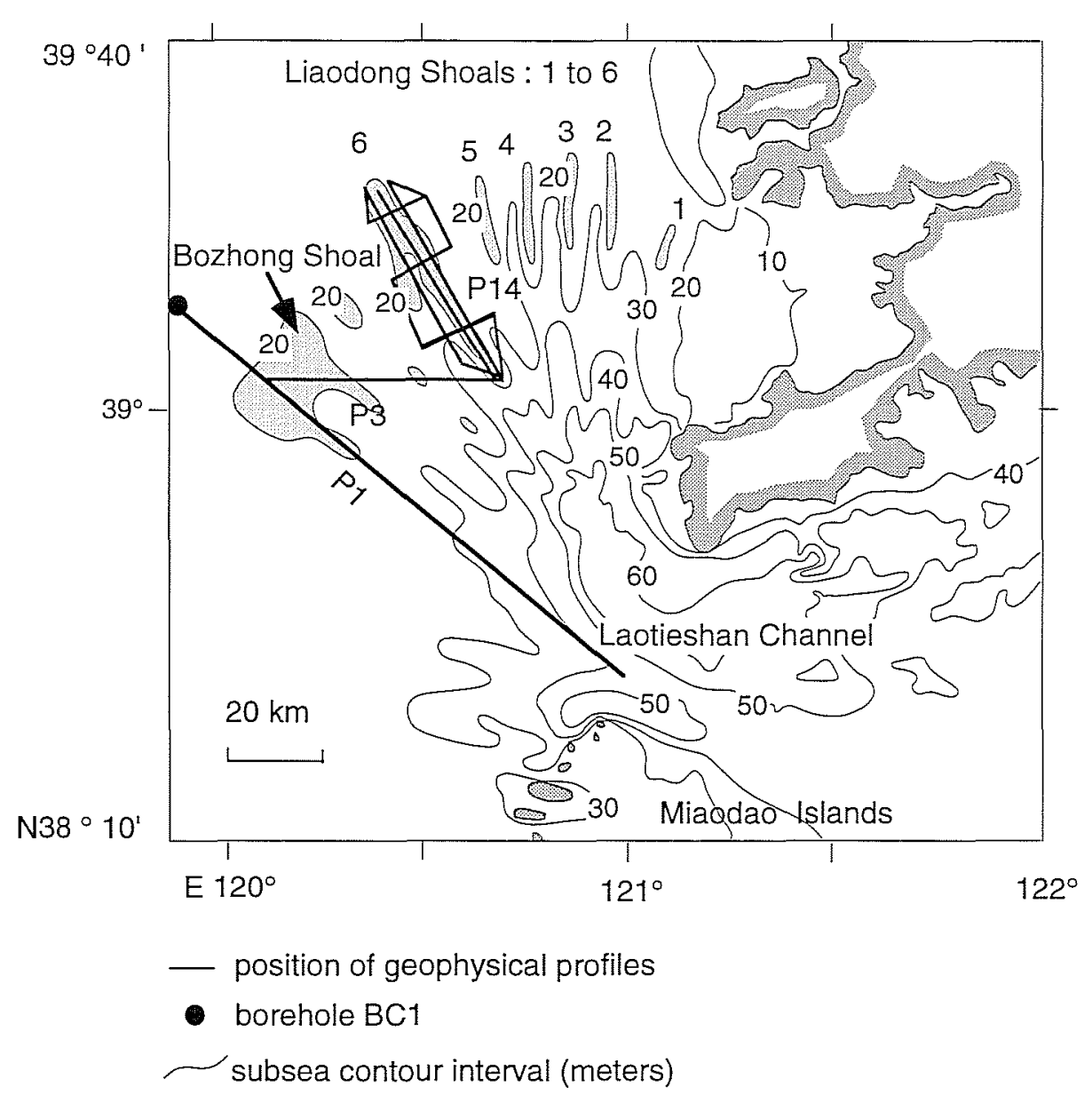

fig. 1b : Area of 1991 survey of the eastern Bohai Sea 


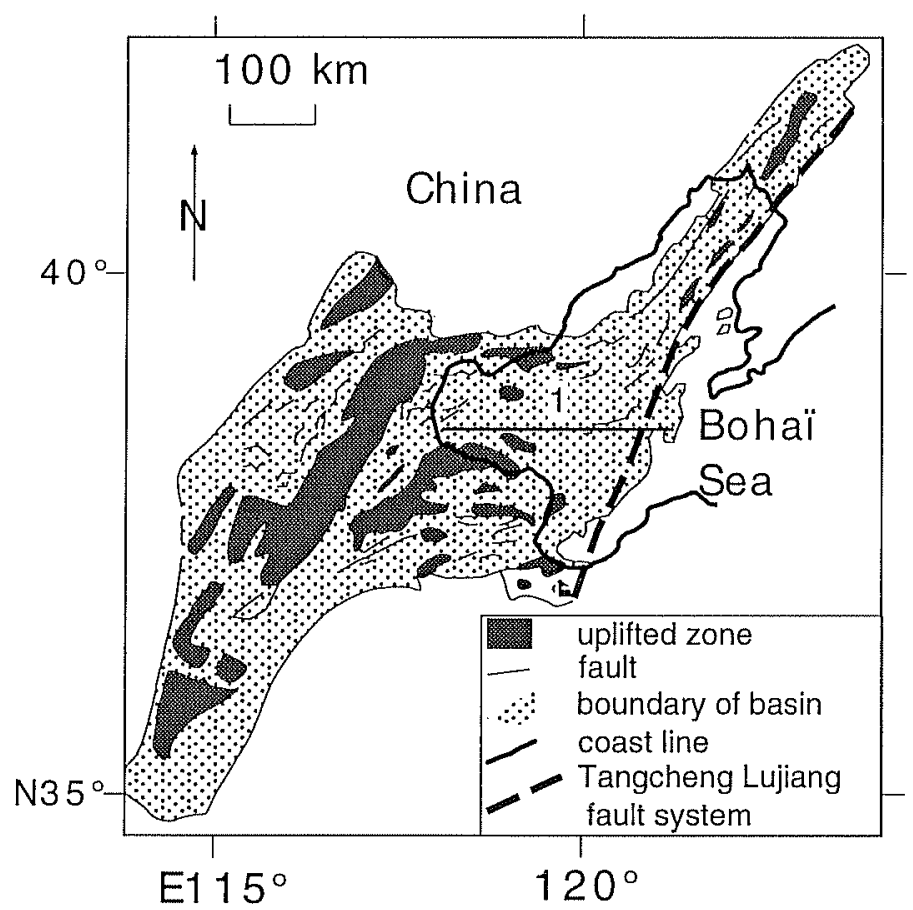

(A) modified from Hsu, 1986 and Hu et al., 1989

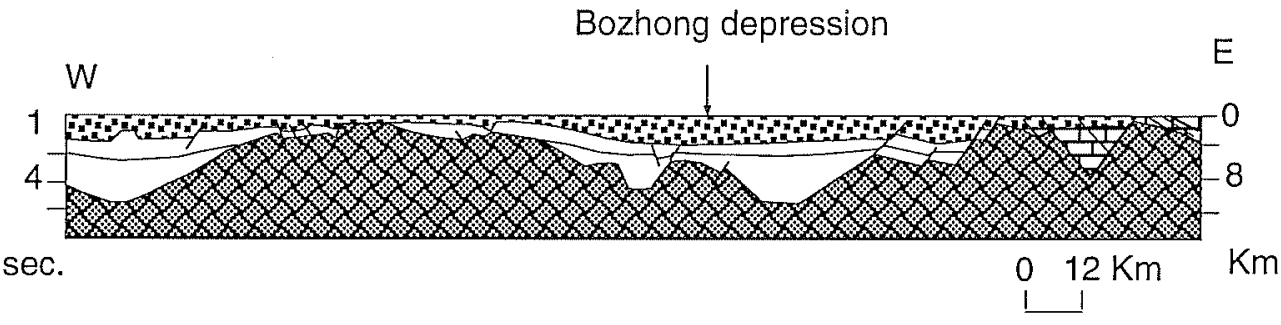

33 Neogene- $\square$ Paleogene Mesozoic Proterozoïc Quaternary

(B) section 1: modified from Hsu, 1986 and Wang, 1994

fig. 2 : Structural outline of the Bohaï Sea and section showing Tertiary and Quaternary deposits 


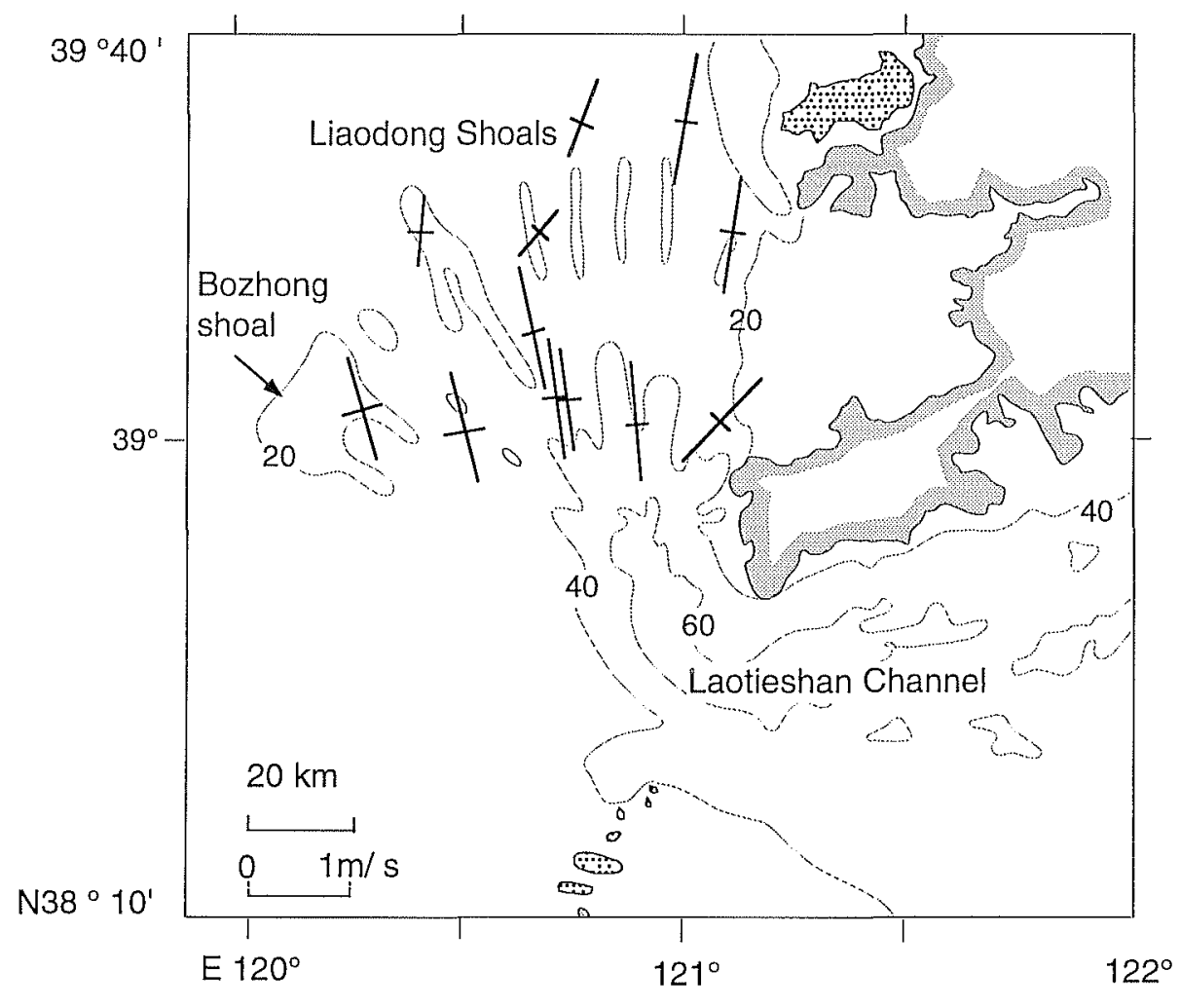

fig. $3:$ M2 tidal ellipses in the Southern part of the Bohai Sea (from Liu et al, 1994) 


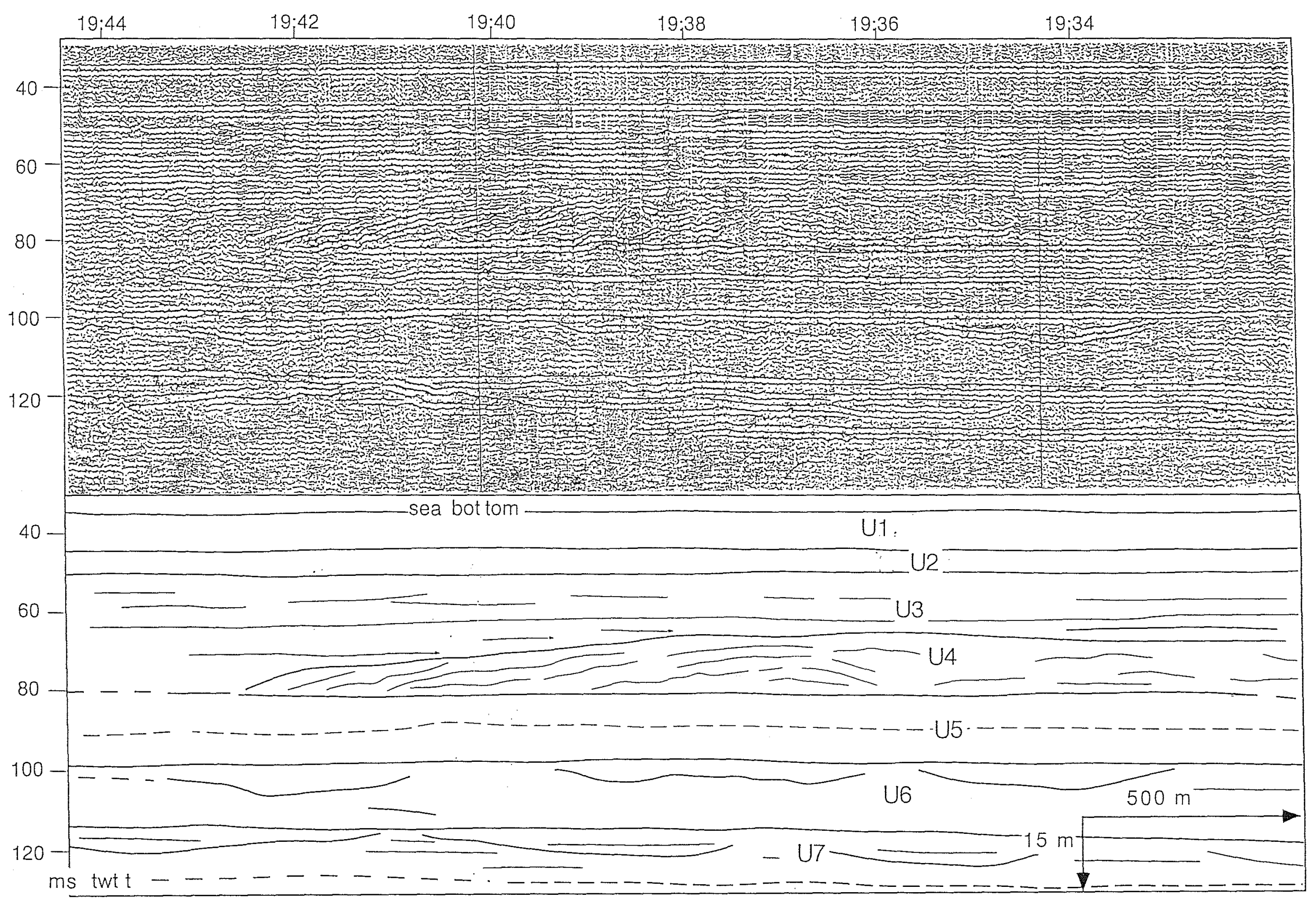

fig. 4 : Major seismic units distinguished by sparker SIG in the vicinity of borehole $\mathrm{BC} 1$ (position shown in figs. $1 \mathrm{~b}$ and 7) 

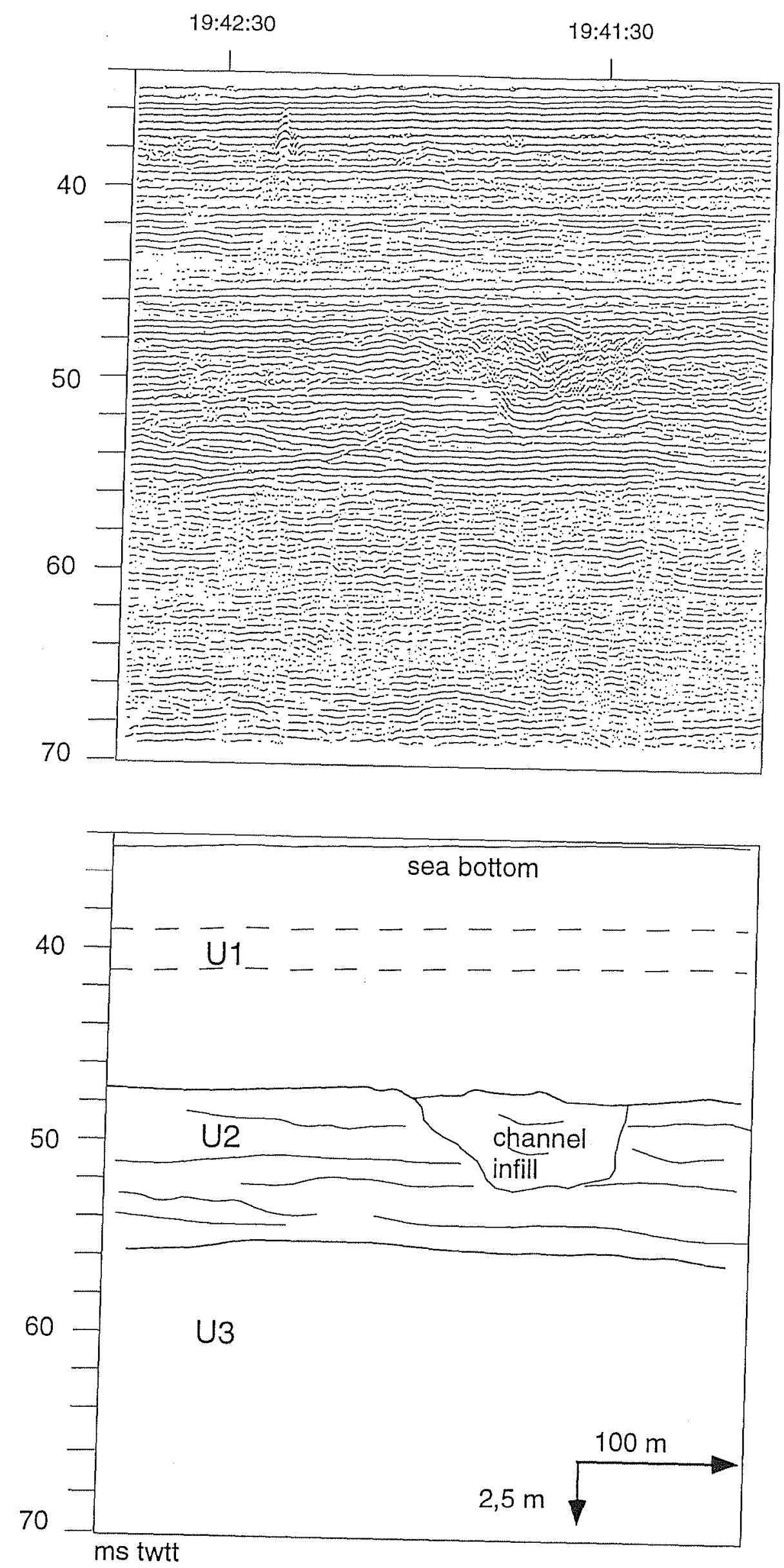

fig. 5: Typical acoustic facies of seismic units U1, U2 and U3, determined by sub-bottom profiler ( $2.5 \mathrm{Khz})$, in the vicinity of borehole $\mathrm{BC} 1$ (position shown in figs. $1 \mathrm{~b}$ and 7 ) 


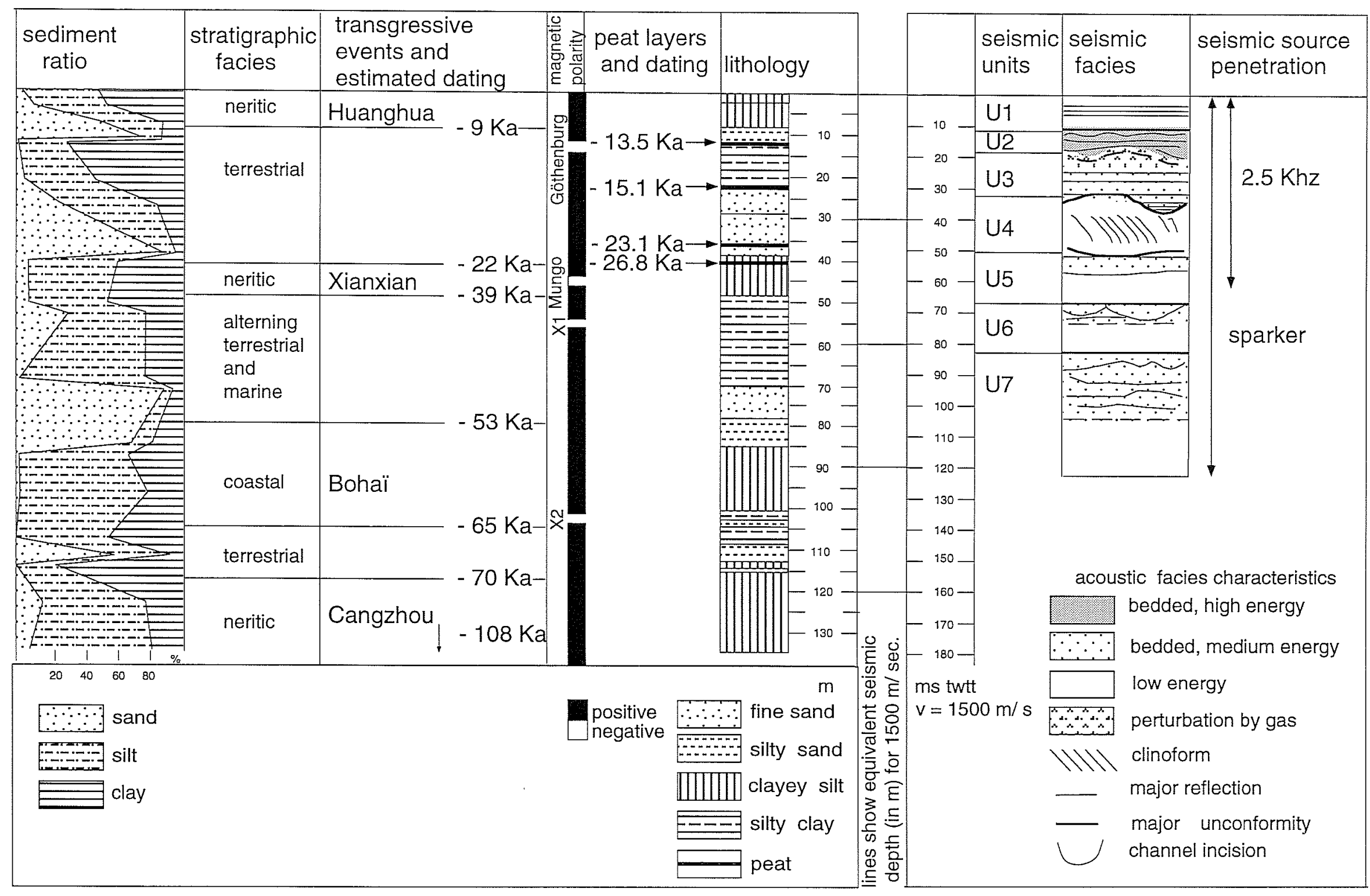
A stratigraphic and sedimentologic analysis
$(\mathrm{Li}, 1985)$

(B) seismic analysis (Bohaï 1991 survey)

fig. 6: multidisciplinary analysis at borehole $\mathrm{BC} 1$ and proposed correlations with seismic units 


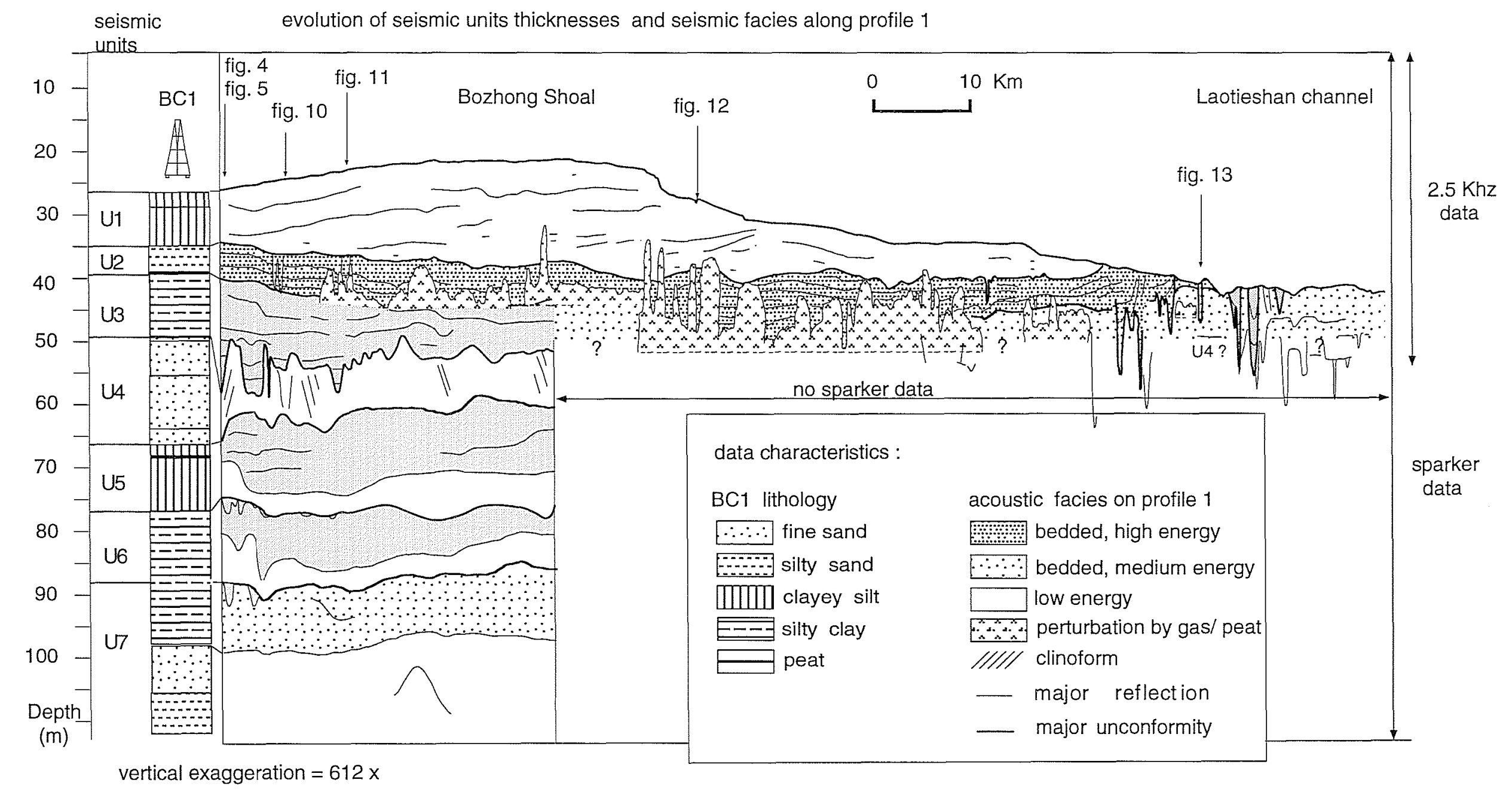

fig. 7 : Seismic interpretation and correlation of units in borehole BC1 in profile 1 (location on fig. 1b) Figs. $4,5,10,11,12,13$ show the positions of selected seismic sections 


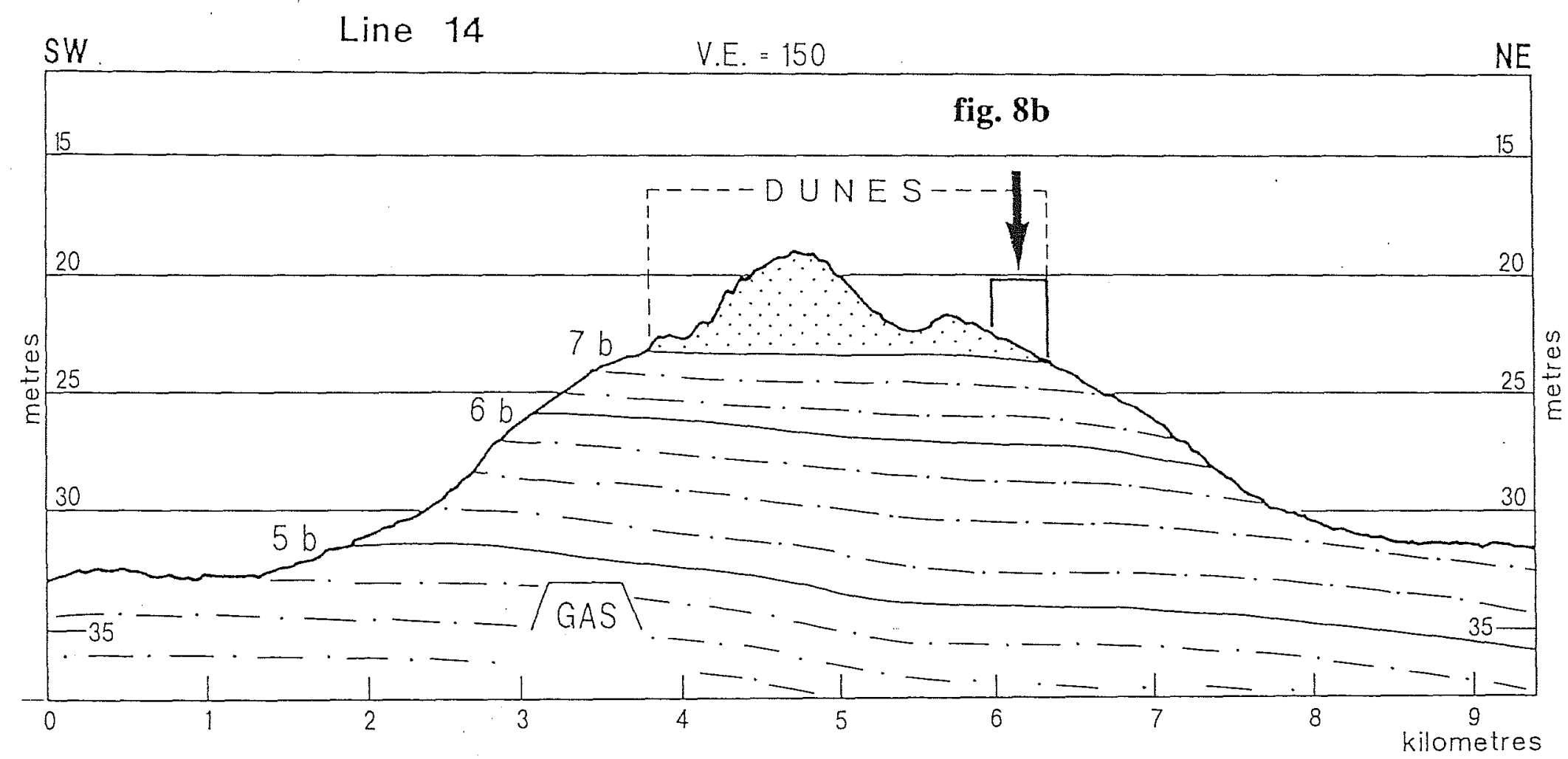

fig. 8a : Seismic interpretation of unit U1 in profile 14 (location shown on fig. 1b). This transversal section of the Liaodong shoal shows internal réflectors $(7 \mathrm{~b}, 6 \mathrm{~b}, 5 \mathrm{~b})$ and the erosive present day surface. Dunes are located on the top of this unit . 

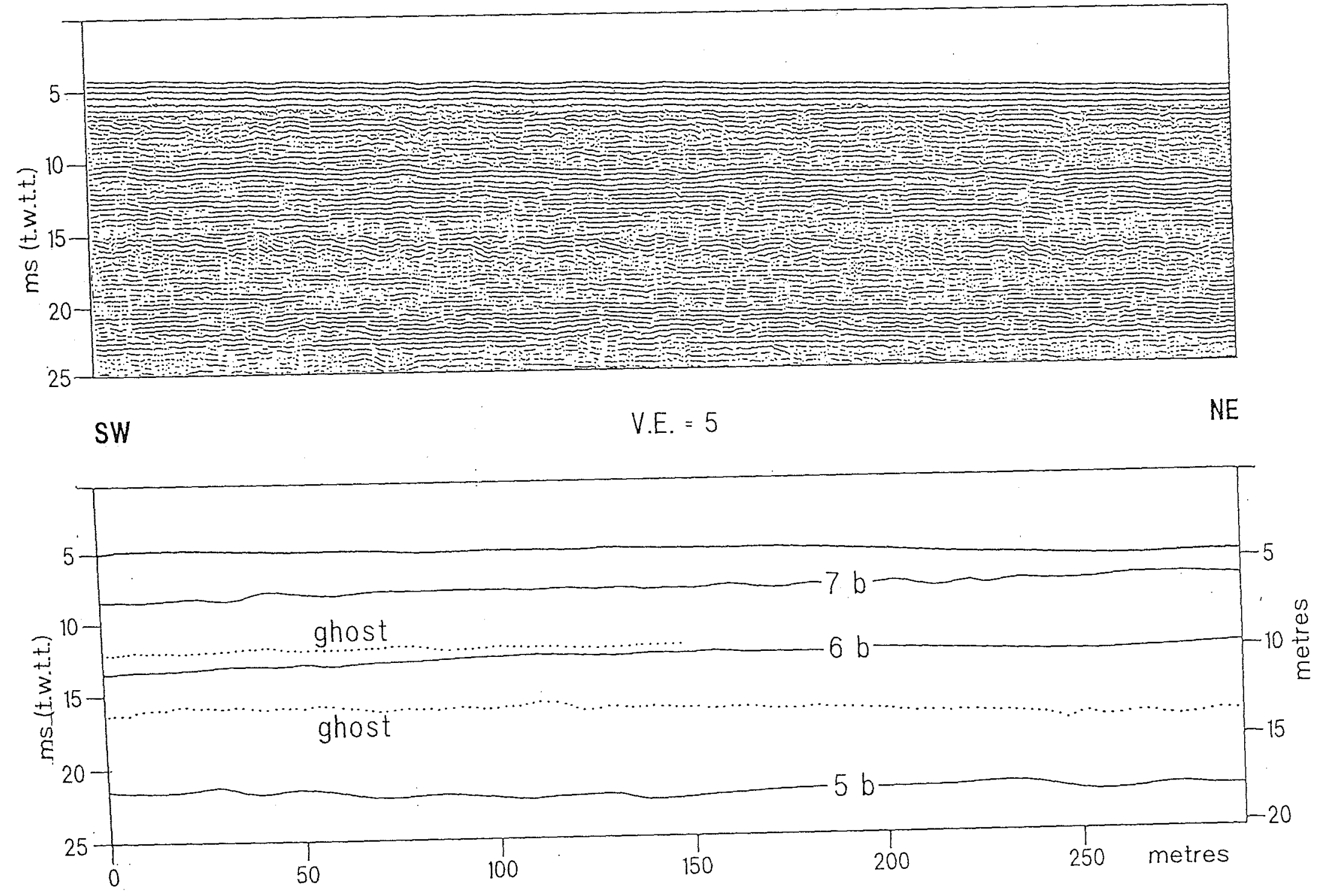

fig. $8 \mathrm{~b}$ : Acoustic facies of seismic unit U1, determined by sub-bottom profiler $2.5 \mathrm{Khz}$, exhibits internal reflectors $7 \mathrm{~b}, 6 \mathrm{~b}$, and $5 \mathrm{~b}$. 


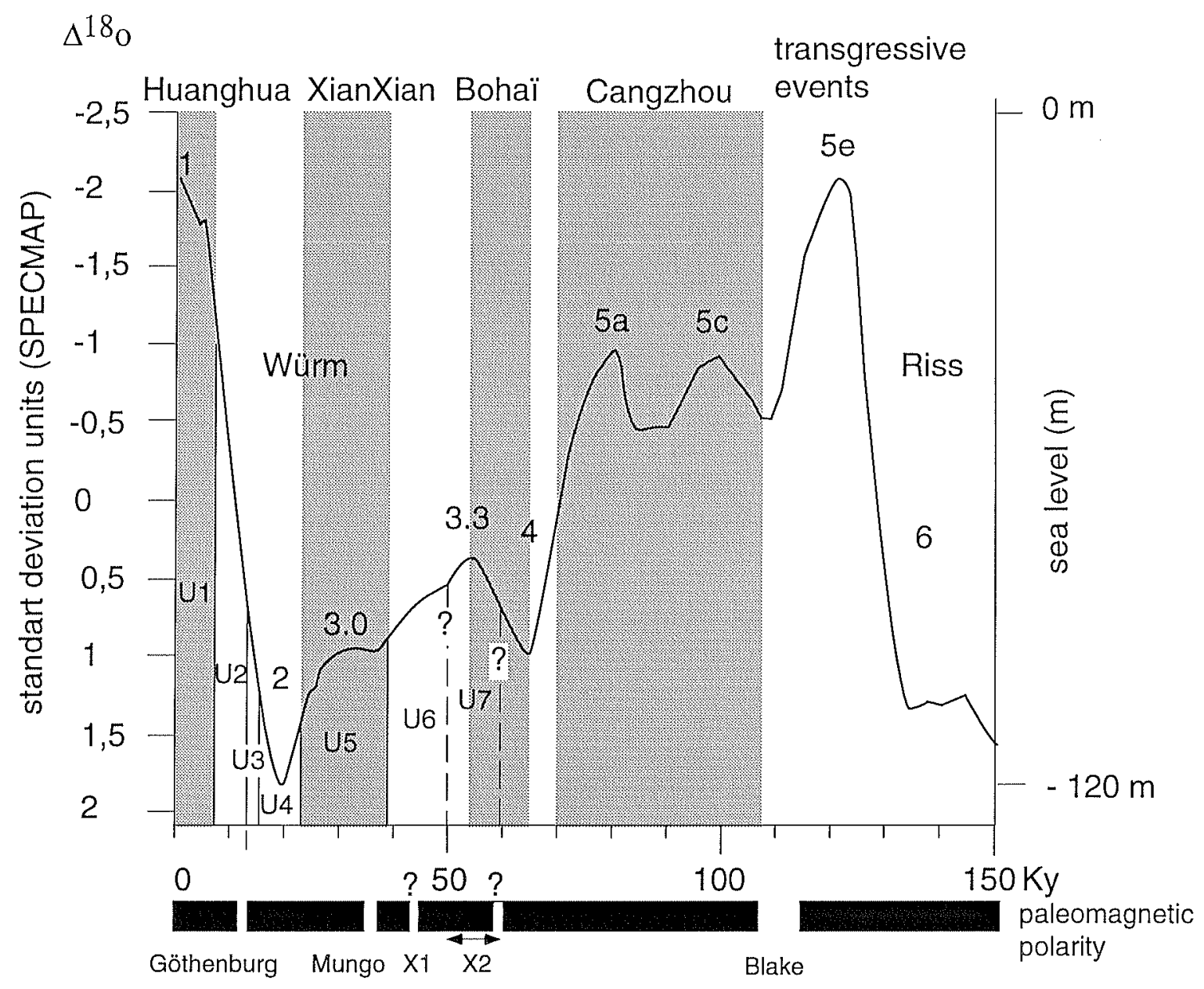

fig. 9: Correlations among oxygen-isotope curve SPECMAP (Imbrie, 1984; Pisias, 1994), stratigraphic units in Borehole BC1 (Qin et al., 1990) and seismic units (this study) 

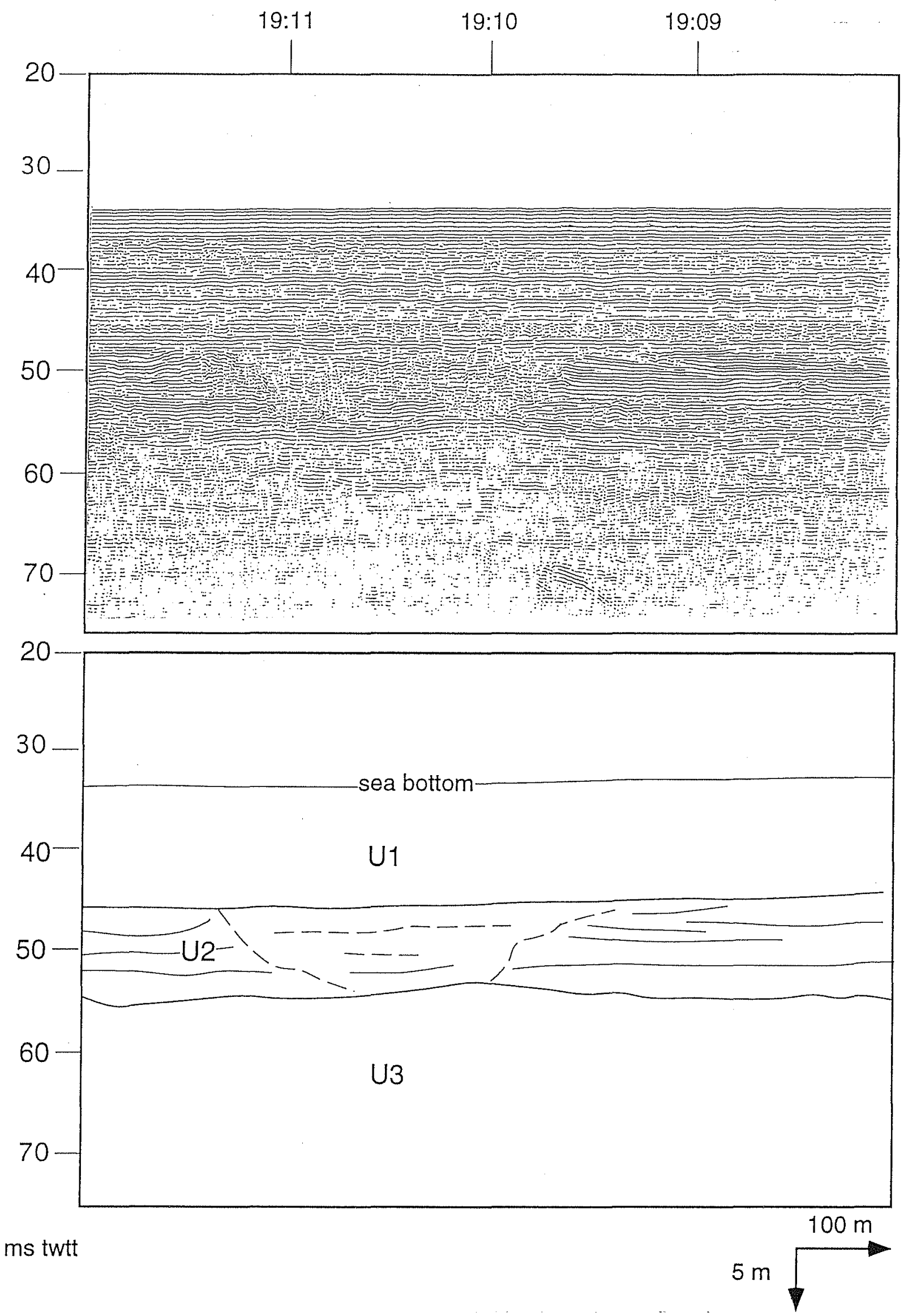

fig. 10 : Acoustic facies of seismic units U1, U2, and U3, determined by sub-bottom profiler $2.5 \mathrm{Khz}$, exhibit infilled channel in seismic unit U2 (position shown in fig. 7) 


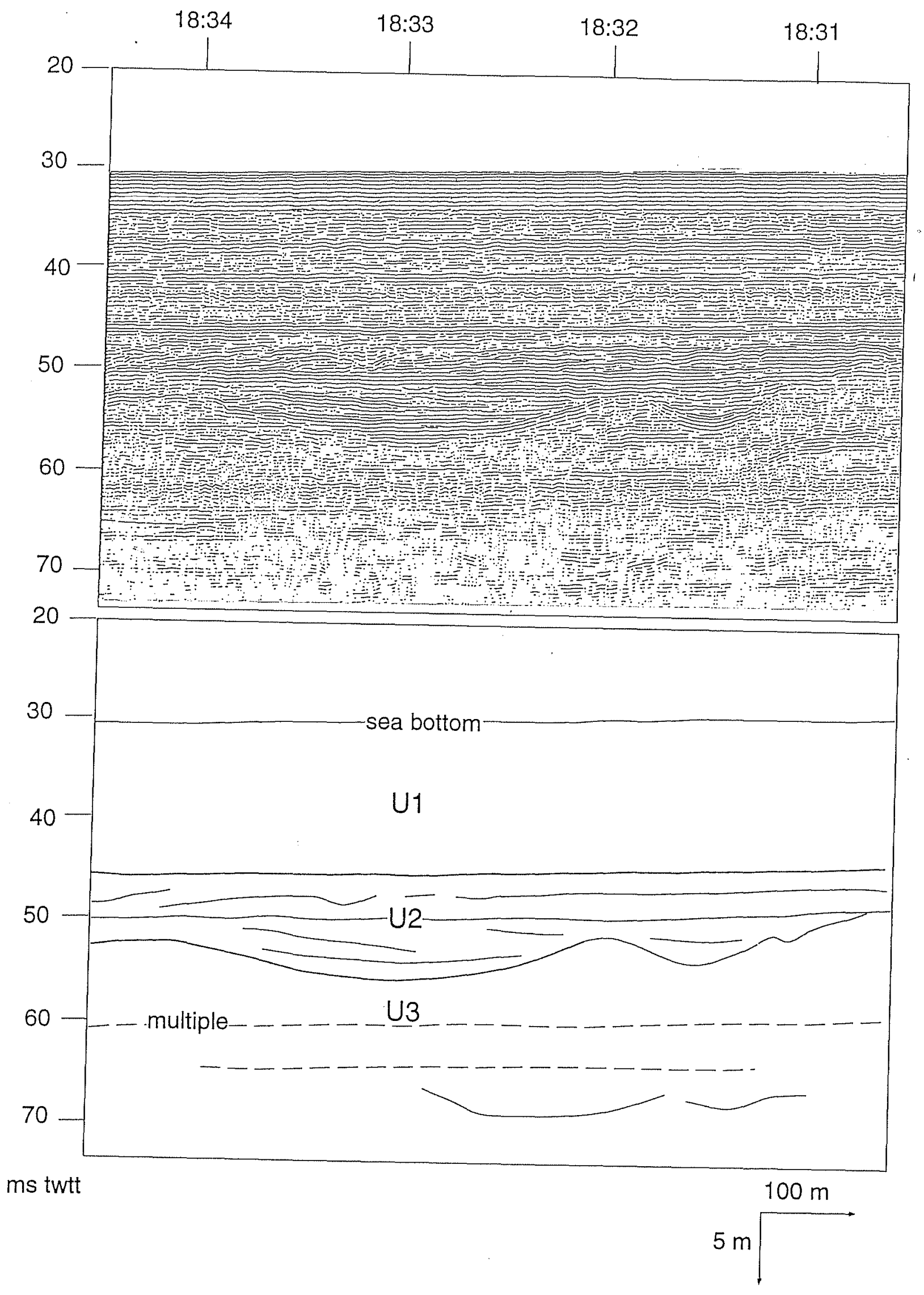

fig. 11: Acoustic facies of seismic units U1, U2, and U3, determined by sub-bottom profiler $2.5 \mathrm{Khz}$, exhibit infilled paleo-channels in units U2 and U3. Unit $\cup 2$ may be divided into 2 sub-units separated by a major discontinuity (position shown in fig. 7) 


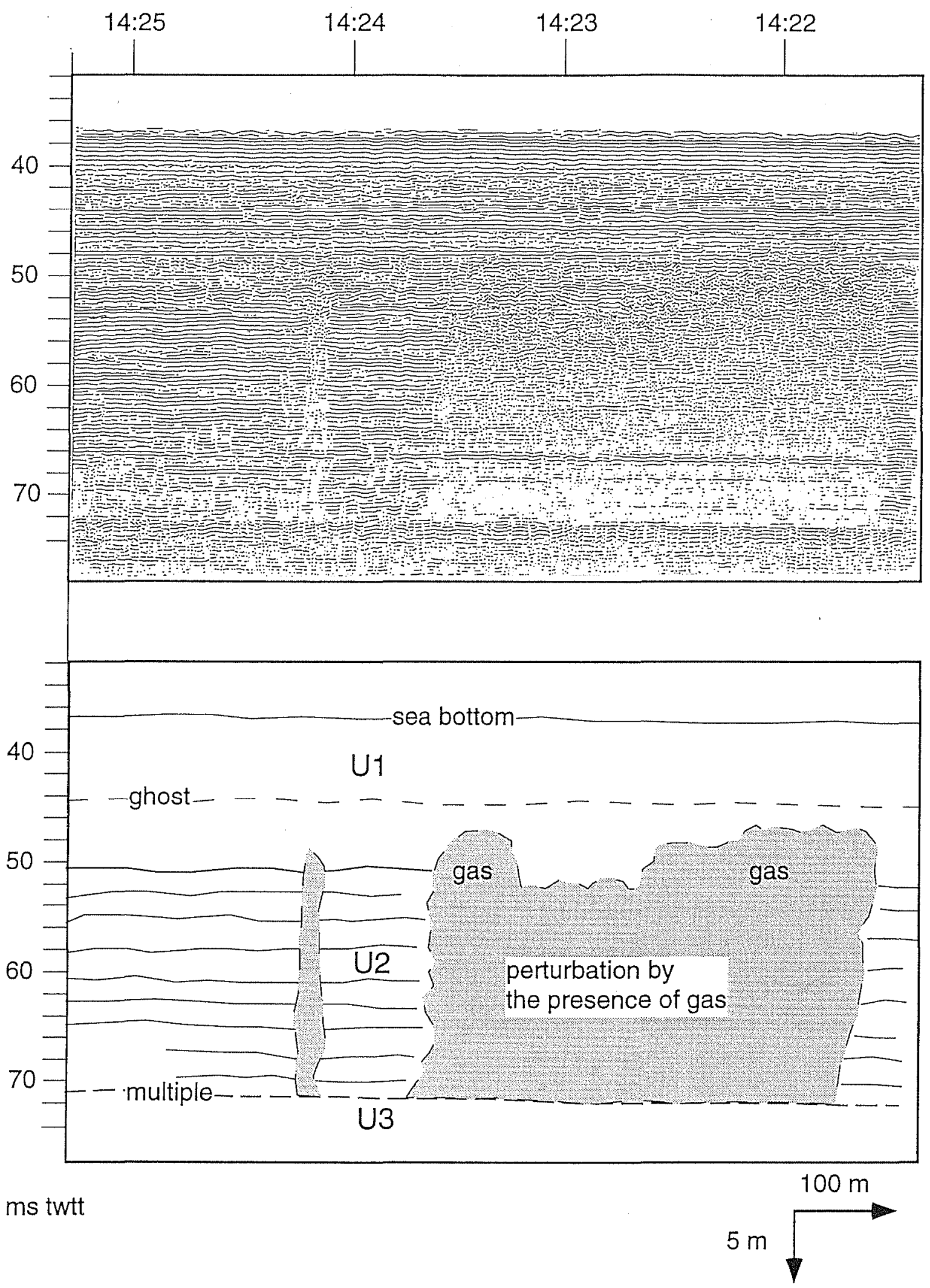

fig. 12 : Seismic section showing acoustic reflectors of seismic units U1, U2, U3, determined by sub-bottom profiler ( $2.5 \mathrm{khz})$, disturbed by the presence of gas (position shown in fig. 7) 

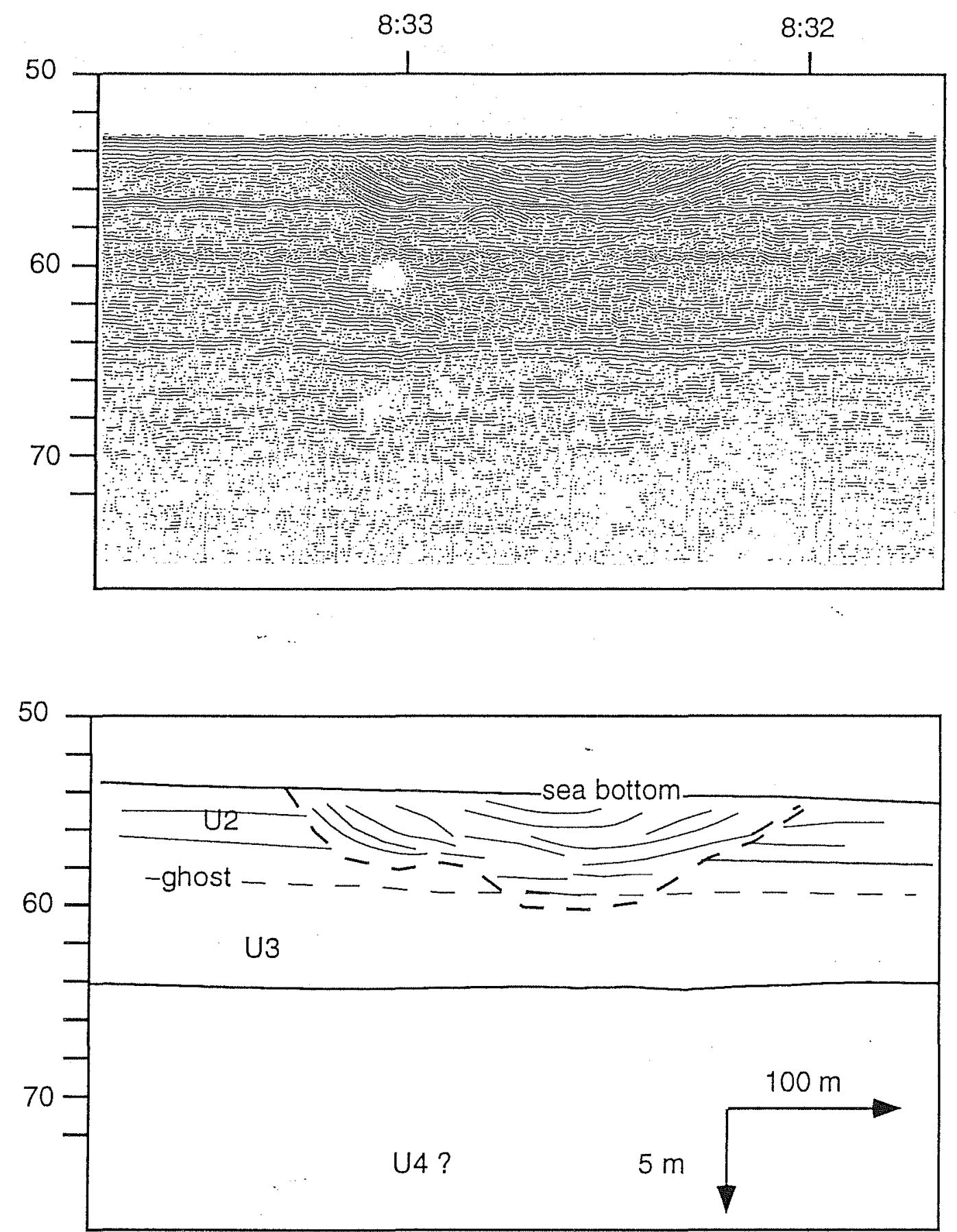

ms twtt

fig. 13: Acoustic facies of seismic units U2, U3, and U4 (?), determined by sub-bottom profiler ( $2.5 \mathrm{Khz})$, exhibit infilled paleo-channel in units $\mathrm{U} 2$ and $\mathrm{U} 3$ (position shown in fig. 7) 